\title{
Pengaruh Opini Audit, Profitabilitas dan Kompleksitas Operasi Perusahaan Terhadap Audit Report Lag pada Perusahaan Pertambangan Periode 2014 - 2018
}

\author{
Shania El Wada \\ Fakultas Eknonomi dan Bisnis, Universitas Muhammadiyah Prof. DR. Hamka \\ shaniaelwadadada@gmail.com \\ Ahmad Subaki \\ Fakultas Ekonomi dan Bisnis, Universitas Muhammdiyah Prof DR. Hamka \\ achmad60subaki@gmail.com \\ Zulpahmi \\ Fakultas Ekonomi dan Bisnis, Universitas Muhammdiyah Prof. DR. Hamka \\ zulpahmi42@gmail.com
}

(Diterima: September-2020; dipublikasikan: Januari-2021)

\begin{abstract}
This study aims to determine how the influence of institutional ownership, independent commissioners, and leverage on risk management disclosures in property and real estate companies listed on the Indonesia Stock Exchange (IDX). In this study the explanatory method is used The sample selection method uses purposive sampling and obtained a sample of 7 companies. The data collection technique used is the document review method that is examining the financial statements obtained from the Indonesia Stock Exchange (IDX) website (www.idx.co.id). Data processing and analysis techniques used are accounting analysis, multiple linear regression analysis, classic assumption test (normality test, multicollinearity test, heteroscedasticity test, and autocorrelation test), hypothesis testing, correlation coefficient analysis, coefficient of determination analysis. The results showed that partially profitability variables significantly influence the audit report lag, this is evidenced by the significance value $0.02<0.05$ and complexity do not have effect to audit report lag, this evidenced by the value -0,587 <2,039.
\end{abstract}

Keywords: Audit Opinion; Profitability; Company Operating Complexity; Audit Report Lag

\begin{abstract}
Abstrak
Penelitian ini bertujuan untuk mengetahui bagaimana pengaruh opini audit, profitabilitas dan kompleksitas operasi perusahaan terhadap audit report lag pada perusahaan pertambangan yang terdaftar di Bursa Efek Indonesia (BEI). Dalam penelitian ini digunakan metode eksplanasi. Metode pemilihan sampel menggunakan purposive sampling dan diperoleh sampel sebanyak 7 perusahaan. Teknik pengumpulandata yang digunakan adalah metode telaah dokumen yaitu menelaah laporan keuangan yang diperoleh dari website Bursa Efek Indonesia (BEI) (www.idx.co.id). Teknik pengolahan dan analisis data yangdigunakan adalah analisis akuntansi, analisis regresi linear berganda, uji asumsi klasik (uji normalitas, uji multikolinearitas, uji heteroskedastisitas, dan uji autokorelasi), uji hipotesis, analisis koefisien korelasi, analisis koefisien determinasi. Hasil penelitian menunjukan bahwa secara parsial variabel profitabilitas berpengaruh secara signifikan terhadap audit report lag hal ini dibuktikan dengan nilai signifikansi profitabilitas $0.02<0.05$ dan kompleksitas operasi perusahaan tidak berpengaruh terhadap audit report lag yang ditunjukkan melalui nilai thitung sebesar $-0,587<2,039$.
\end{abstract}

Kata Kunci: Opini Audit; Profitabilitas; Kompleksitas Operasi Perusahaan; Audit Report Lag 


\section{PENDAHULUAN}

Informasi akuntansi yang tercantum dalam laporan keuangan perusahaan dapat bermanfaat apabila disajikan secara akurat, dan tepat waktu untuk pengambilan keputusan oleh para pengguna laporan keuangan, seperti kreditor, investor, pemerintah, masyarakat dan pihak- pihak lain. Investor merupakan salah satupihak yang memiliki kepentingan dengan perolehan informasi keuangan yang tepat waktu, implikasinya meningkatkan kepercayaan investor dalam melakukan keputusan investasi (Sumartini dan Widhiyani2014).

Selanjutnya, audit report lag merupakanperbedaan waktu antara tanggal laporan keuangan dengan tanggal opini audit dalam laporan keuangan yang mengindikasikan tentang lamanya waktu penyelesaian audit yangdilakukan oleh auditor. Semakin panjang audit report lag maka akan semakin lama auditor dalam menyelesaikan pekerjaan auditnya Tujuan menyeluruh dari suatu audit laporan keuangan adalah menyatakan pendapat apakah laporan keuangan klien telah menyajikan secara wajar dalam semua hal yang material sesuai dengan prinsip akuntansi yang berlaku umum, (Hariza, Wahyuni dan Maria,2012).

Opini audit diberikan oleh auditor melalui beberapa tahap audit sehingga auditor dapat memberikan kesimpulan atas opini yang harus diberikan atas laporan keuangan yang telah diauditnya. Jangka waktu proses penyelesaian audit dapat berbeda satu dengan lainnya antara perusahaan yang memperoleh pendapat wajar tanpa pengecualian dengan pendapat audit lainnya (Sumartini dan Widhiyani 2014).

Profitabilitas adalah kemungkinan yang diprediksi untuk mendatangkan keuntungan atau laba. Tingkat profitabilitas perusahaan dapat diukur melalui rasio profitabilitas. Semakin tinggi rasio profitabilitas maka laba yang dihasilkan akan semakin besar. Ada perbedaan perlakuan laporan keuangan oleh manajemen ketika perusahaan mendapatkan tingkat profitabilitas yang tinggi dan rendah.

Perusahaan yang mempunyai rugi atau tingkat profitabilitas rendah nantinya akan membawa dampak buruk dari reaksi pasar dan akan menyebabkan turunnya penilaian kinerja suatu perusahaan.

Kompleksitas operasi perusahaan, penelitian yang dihasilkan (Hariani dan Darsono 2014). Tingkat kompleksitas operasi merupakan sebuah perusahaan yang bergantung pada jumlah dan lokasi unit oprasinya (cabang) serta diversifikasi jalur produksi dan pasarnya. Hal tersebut mempengaruhi waktu yang dibutuhkan auditor untuk menyelesaikan pekerjaan auditnya. Hal ini juga didukung teori agensi semakin besar ukuran operasi perusahaan akan semakin banyak dalam mengungkap informasi dan meningkatkan agensicost. Maka akan membuat semakin lamanya prosesaudit.

Berdasarkan latar belakang yang telah dikemukakan di atas, maka permasalahan yang akan dibahas dapat dijabarkan sebagai berikut:

1. Bagaimanakah pengaruh opini audit terhadap audit report lag?

2. Bagaimanakah pengaruh profitabilitas terhadap audit report lag?

3. Bagaimanakah pengaruh kompleksitas operasi perusahaan terhadap audit report lag?

4. Bagaimanakah pengaruh opini audit, profitabilitas dan kompleksitas operasi perusahaan terhadap audit report lag?

Tujuan dilakukannya penelitian adalah:

1. Untuk mengetahui pengaruh opini audit terhadap audit report lag pada Perusahaan Pertambangan yang terdaftar di Bursa Efek Indonesia.

2. Untuk mengetahui pengaruh profitabilitas terhadap audit report lag pada Perusahaan Pertambangan yang terdaftar di Bursa Efek Indonesia.

3. Untuk mengetahui pengaruh kompleksitas operasi perusahaan terhadap audit report lag pada Perusahaan Pertambangan yang terdaftar di Bursa Efek Indonesia.

4. Untuk mengetahui pengaruh opini audit, profitabilitas, dan kompleksitas operasi perusahaan secara simultan terhadap audit report lag pada Perusahaan Pertambangan yang terdaftar di Bursa EfekIndonesia. 


\section{Kajian Teori}

\section{Audit Report Lag}

Audit report lag termasuk karakteristik kualitatif yang harus di penuhi dalam laporan keuangan, yaitu sifat relevan. Laporan keuangan dikatakan tidak relevan saat laporan keuangan tidak disampaikan tepat waktu, sehingga kehilangan manfaat untuk mempengaruhi keputusan yang akan diambil oleh penguna laporan keuangan perusahaan. Ketepatan penerbitan laporan keuangan auditan merupakan hal yang sangat penting bagi perusahaan dan pengguna laporan keuangan (Shabrina,2014)

Audit Report Lag $=$ Tanggal Laporan Auditor Independen - Tanggal

Laporan Keuangan

\section{Opini Audit}

Opini audit adalah laporan yang diberikan seorang akuntan publik terdaftar sebagai hasil penilaiannya atas kewajaran laporan keuangan yang disajikan perusahaan (Ardiyos, 2017).

$$
\text { ROA }=\frac{\text { Laba Bersih }}{\text { Total Aset }} \times 100 \%
$$

\section{Profitabilitas}

Profitabilitas suatu perusahaan akan memengaruhi kebijakan para investor atas investasi yang dilakukan. Kemampuan perusahaan dalam menghasilkan laba akan menarik minat para investor guna memperluas usahanya dengan melakukan penanaman modal, sebaliknya tingkat profitabilitas yang rendah akan menyebabkan para investor menarik dananya (PatikodanSambo,2015:47).

\section{Kompleksitas Operasi Perusahaan}

Kompleksitas operasi perusahaan merupakan akibat langsung dari pembagian pekerjaan dan pembentukan departemen yang berfokus pada unit yang berbeda. Kompleksitas operasi perusahaan berhubungan dengan unitunit perusahaan yang saling bekerjasama dan saling memengaruhi untuk mencapai tujuan perusahaan. Kegiatan operasi yang semakin kompleks terjadi apabila organisasi dengan berbagai jenis pekerjaan dan unitmenimbulkan masalah manajerial dan organisasi yang lebih rumit (Martius,2012:12).

Kompleksitas Operasi Perusahaan = Jumlah Anak Perusahaan

\section{Kerangka Teoritis}

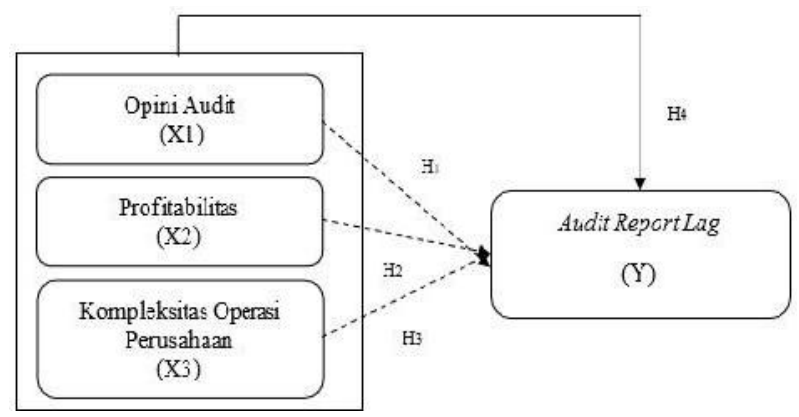

\section{METODE PENELITIAN}

Metode yang digunakan dalam penelitian ini adalah metode eksplanasi, karena dalam penelitian ini menggunakan dua variabel. Metode eksplanasi adalah suatu metode penelitian yang menggambarkan dua variabel yang diteliti, yaitu variabel bebas (independen) dan variabel terikat (dependen) yang kemudian menjelaskan hubungan atau pengaruh kedua variabel tersebut.

\section{HASIL DAN PEMBAHASAN}

\section{Analisis Statistik Deskriptif}

Analisis ini digunakan untukmenunjukkan jumlah data yang digunakan dalam penelitian ini serta dapat menunjukkan nilai tertinggi (maksimum), nilai terendah (minimum), nilai rata-rata (mean) dan nilai standar deviasi (standar deviation) dari masing-masing variabel yang telah diolah menggunakan SPSS versi23.

\section{Tabel 1 Analisis Statistik Deskriptif}

\begin{tabular}{|c|c|c|c|c|c|c|}
\hline \multicolumn{7}{|c|}{ Descriptive Stetistics } \\
\hline & \multirow{2}{*}{$\frac{\mathrm{N}}{\mathrm{Staistic}}$} & \multirow{2}{*}{$\begin{array}{l}\text { Mirimum } \\
\text { Statistic }\end{array}$} & \multirow{2}{*}{$\begin{array}{l}\text { Waximum } \\
\text { Stalisti: }\end{array}$} & \multicolumn{2}{|c|}{ Mean } & \multirow{2}{*}{$\begin{array}{c}\text { Sid. Devistisn } \\
\text { Stelist: }\end{array}$} \\
\hline & & & & S:atstic & Std Error & \\
\hline Cpini fudf & 35 & ) & 1 & .63 & .081 & .432 \\
\hline Piültabilias & 35 & .23 & 20.34 & ถ. 1893 &.$\$ 3521$ & $5.828 \bar{x}$ \\
\hline Komplekeitus Jzeres & & & & & & \\
\hline Penısahaลา & 35 & )] & 1 & .71 & (ITT) & .458 \\
\hline Audi: Keport Lag & 35 & $36.0]$ & $147.0]$ & $65 . .571$ & $3.63 \times 03$ & $21.511 \mathrm{JT}$ \\
\hline Valic N (listwice) & 35 & & & & & \\
\hline
\end{tabular}

Sumber: Output SPSS versi 23. 
Berdasarkan tabel tersebut, dapat dilihat bahwa variabel opini audit (X1) dengan jumlah data $(\mathrm{N})$ sebanyak 35 memiliki rata-rata (mean) sebesar 0,66 dengan nilai minimum 0 dan nilai maksimum sebesar 1, sedangkan standar deviasinya sebesar0,482.

Variabel profitabilitas (X2) dengan jumlah data $(\mathrm{N})$ sebanyak35memilikirata rata6,1898 dengan nilai minimum 0,28 dan nilai maksimum 20,34 , sedangkan standar deviasinya sebesar 5,82858 .

Variabel kompleksitas operasi perusahaan (X3) dengan jumlah data (N) sebanyak 35 memiliki rata-rata 0,71 dengan nilai minimum 0 dan nilai maksimum 1 sedangkan, standar deviasinya sebesar 0,458 .

Audit report lag $(\mathrm{Y})$ dengan jumlah $(\mathrm{N})$ sebanyak 35 memiliki rata-rata sebesar 66,4571 dengan nilai minimum sebesar 38,00 dan maksimum 147,00 sedangkan, standar deviasinya sebesar21,51107.

\section{Analisis Regresi Linear Berganda}

Model regresi linear berganda untuk membuktikan ada atau tidaknya hubungan fungsional antara variabel bebas (X) dengan sebuah variabel terikat (Y). Analisis regresi linear berganda dalam penelitian ini digunakan untuk mengetahui pengaruh Opini Audit, Profitabilias, dan Kompleksitas Operasi Perusahaan terhadap Audit Report Lag.

Tabel 2 Analisis Regresi Linear Berganda

\begin{tabular}{|c|c|c|c|c|c|c|}
\hline \multicolumn{7}{|c|}{ Coefficients ${ }^{a}$} \\
\hline \multirow[b]{2}{*}{ Mode } & & \multicolumn{2}{|c|}{$\begin{array}{l}\text { Unsiandardized } \\
\text { Coefficients }\end{array}$} & \multirow{2}{*}{$\begin{array}{c}\begin{array}{c}\text { Standerdized } \\
\text { Coefficients }\end{array} \\
\text { Beta }\end{array}$} & \multirow[b]{2}{*}{$\mathrm{t}$} & \multirow[b]{2}{*}{ Sig. } \\
\hline & & B & Std. Emor & & & \\
\hline 1 & (Constant) & 9. 49 & .458 & & 19.991) & .000 \\
\hline & Oojn Audit & .477 & .407 & .188 & 1.172 & $.25)$ \\
\hline & Profitablitas & .557 & .167 & -542 & -3.347 & .002 \\
\hline & Kompleksitas Cpe'asi Perusahaan & .246 & .420 & -093 & -.587 & .561 \\
\hline
\end{tabular}

Sumber: Output SPSS versi 23.

Dari tabel di atas, maka diperoleh persamaan regresi sebagai berikut:

$\hat{\mathrm{Y}}=9,149+0,477 \mathrm{X} 1-0,557 \mathrm{X} 2-0,246 \mathrm{X} 3$

Dari persamaan regresi linear berganda tersebut dapat diinterpretasikan sebagai berikut:

Konstanta sebesar 9,149 artinya jika variabel Opini Audit (X1), Prifitabilitas (X2), dan
Kompleksitas Operasi Perusahaan (X3) nilainya 0, maka Audit Report Lag (Y) nilainya sebesar 9,149.

Koefisien regresi Opini Audit(X1) bernilai positif sebesar 0,477 , artinya jika variabel Opini Audit (X1) mengalami kenaikan sebesar 1\% dengan asumsi X2, X3 tetap, maka Audit Report Lag(Y) mengalami kenaikan sebesar 0,477 dan sebaliknya.

Koefisien regresi Profitabilitas (X2) bernilai negative sebesar $-0,557$, artinya jika variabel Profitabilitas (X2) mengalami kenaikan $1 \%$ dengan asumsi X1, X3 tetap, maka Audit Report Lag (Y) turun sebesar - 0,557 dansebaliknya.

Koefisien regresi Kompleksitas Operasi Perusahaan (X3) bernilai negatif sebesar 0,246, artinya jika variabel Kompleksitas Operasi Perusahaan (X3) mengalami kenaikan sebesar $1 \%$ dengan asumsi X1, X2 tetap, maka Audit Report Lag (Y) turun sebesar 0,246 dan sebaliknya.

UjiNormalitas

Uji normalitas bertujuan untuk menguji dalam model regresi variabel pengganggu atau residual memiliki distribusi normal atau tidak. Uji statistik yang dapat digunakan untuk menguji normalitas residual adalah dengan melihat grafik Normal P-P Plot of Regression Standardized Residual. Model regresi dikatakan memenuhi asumsi normalitas apabila data menyebar di sekitar garis diagonal (Imam Ghozali,2012).

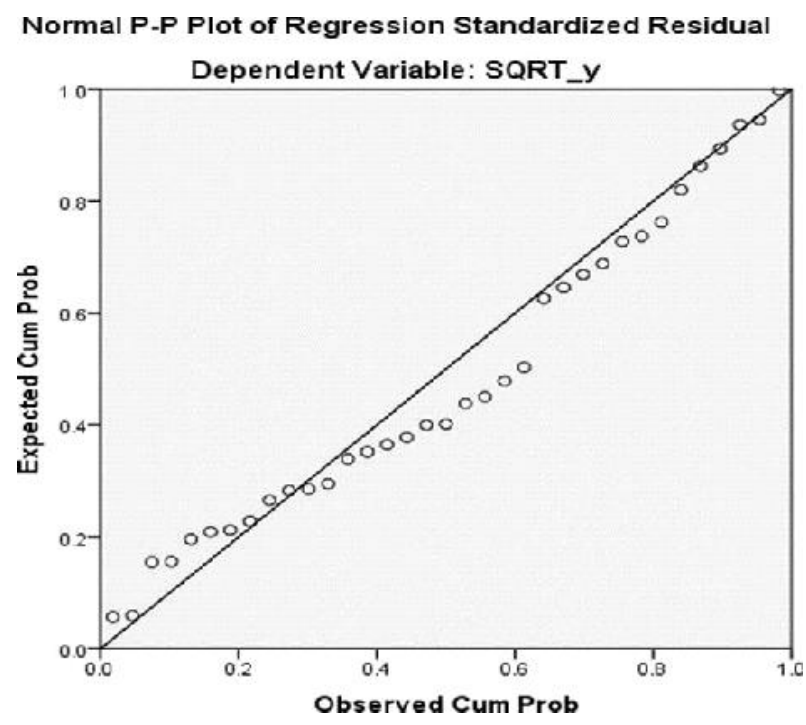

Gambar 1 Grafik Normal P-P Plot of Regression Standardized Residual 
Tabel 3 Hasil Uji Normalitas

\begin{tabular}{|ll|r|}
\hline & & $\begin{array}{r}\text { Unstandardized } \\
\text { Residual }\end{array}$ \\
\hline $\mathrm{N}$ & Mean & 35 \\
Normal Parameters & .0000000 \\
Most Extreme Differences & Std. Deviation & 1.02749392 \\
& Absolute & .126 \\
& Positive & .126 \\
Test Statistic & Negative & -.087 \\
Asymp. Sig. (2-tailed) & & .126 \\
\hline
\end{tabular}

Sumber: Output SPSS versi 23.

Berdasarkan hasil pengujian pada tabel di atas, tingkat signifikansi dari uji normalitas sebesar $0,179>0,05$, maka dapat diinterpretasikan bahwa kesalahan pengganggu berdistribusi normal.

\section{Uji Multikoleniaritas}

Uji multikolinearitas bertujuan untuk menguji model regresi ditemukan atau tidak korelasi antar variabel bebas (independen). Model regresi yang baik seharusnya tidak terjadi korelasi di antara variabel-variabel independen.

Pengujian ini dilakukan dengan menghitung nilai tolerance dan Variance Inflation Factor (VIF). Jika nilai Variance Inflation Factor (VIF) tidak lebih dari 10 (VIF < 10) dan nilai tolerance tidak kurang dari $0,10(10 \%)$, maka dapat dikatakan terbebas dari multikolinearitas (Imam Ghozali, 2012:105-106).

Tabel 4 Hasil Uji Multikoleniaritas

\begin{tabular}{|cl|c|c|}
\hline \multirow{2}{*}{\multicolumn{2}{|c|}{ Model }} & \multicolumn{2}{c|}{ Collinearity Statistics } \\
\cline { 2 - 4 } & Tolerance & VIF \\
\hline $1 \quad$ (Constant) & .885 & 1.130 \\
& Opini Audit & .871 & 1.148 \\
& $\begin{array}{l}\text { Profitabilitas } \\
\text { Kompleksitas Operasi } \\
\text { Perusahaan }\end{array}$ & .921 & 1.086 \\
\hline
\end{tabular}

Sumber: Output SPSS versi 23.

Tabel di atas menunjukkan bahwa nilai VIF pada Opini Audit sebesar 1,130, Profitabilitas sebesar 1,148, dan Kompleksitas Operasi Perusahaan sebesar 1,086 yang berarti tidak ada yang melebihi angka 10 (VIF < 10). Kemudian nilai tolerance Opini Audit sebesar 0,885, Profitabilitas sebesar 0,871 dan Kompleksitas Operasi Perusahaan sebesar 0,921 yang berarti tidak ada yang kurang dari 0,10 (tolerance> 0,10). Dari nilai VIF dan tolerance tersebut dapat diinterpretasikan bahwa model regresi pada penelitian ini tidak terjadi mutikolinearitas.

\section{Uji Heteroskedastisitas}

Uji heteroskedastisitas bertujuan untuk menguji model regresi ada atau tidaknya ketidaksamaan varian dari residual satu pengamatan ke pengamatan lain. Jika varian dari residual satu pengamatan ke pengamatan lain berbeda maka disebut heteroskedastisitas (Imam Ghozali, 2012: 139).

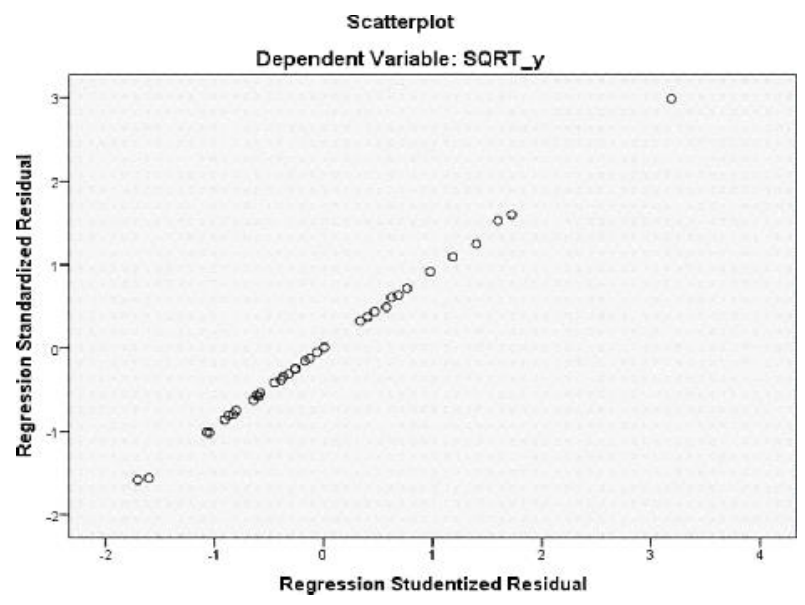

Gambar 2 Grafik Scatterplot

Dari gambar di atas, terlihat bahwa titiktitik tidak terlalu menyebar secara merata acak di atas dan di bawah angka 0 pada sumbu Y, serta ada sedikit yang menumpuk. Hal ini mengindikasikan terjadi heteroskedastisitas pada model regresi.

\section{Uji Autokorelasi}

Autokorelasi adalah keadaan di mana terjadinya korelasi antara residual pada satu pengamatan dengan pengamatan lain pada model regresi. Uji autokorelasi digunakan untuk mengetahui ada atau tidaknya korelasi antara residual pada satu pengamatan dengan pengamatan lain pada model regresi. Model regresi yang baik adalah yang bebas autokorelasi. Metode pengujian menggunakan uji DurbinWatson (uji DW). 
Tabel 5 Hasil Uji Autokorelasi

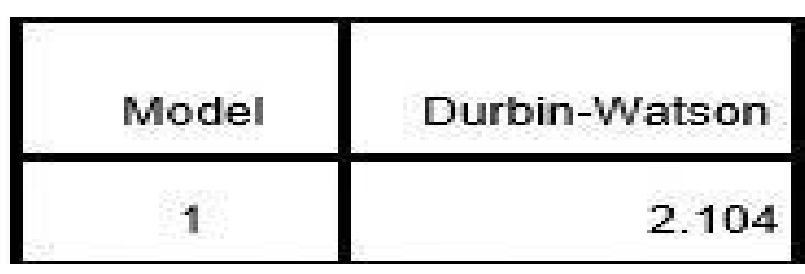

Sumber: Output SPSS versi 23.

Dari hasil output model summary di atas dapat dilihat nilai Durbin-Watson dari hasil pengujian adalah 2,104. Dari jumlah data $(n)=$ 35 dan $\mathrm{k}=3$ (merupakan jumlah variabel independen) diperoleh nilai dL sebesar 1,283 dan nilai dU sebesar 1,653. Nilai DurbinWatson sebesar 2,104 terletak pada daerah du $<$ DW < 4-du $(1,653<2,104<2,347)$, maka dapat diinterpretasi bahwa tidak terjadi masalah autokorelasi pada model regresi.

\section{Uji Statistik $t$}

Uji t pada dasarnya menunjukkan signifikan atau tidaknya pengaruh satu variabel independen secara individual dalam menerangkan variasi variabel dependen. Pengujian dilakukan dengan membandingkan thitung dengan ttabel.

\section{Tabel 6 Uji Statistik t}

\begin{tabular}{|c|c|c|c|c|c|c|}
\hline \multicolumn{7}{|c|}{ Coefficients ${ }^{\circ}$} \\
\hline \multirow[b]{2}{*}{ Model } & & \multicolumn{2}{|c|}{$\begin{array}{c}\text { Unstandardized } \\
\text { Coefficients }\end{array}$} & \multirow{2}{*}{\begin{tabular}{|c|}
$\begin{array}{c}\text { Slandardized } \\
\text { Coetficients }\end{array}$ \\
Beta \\
\end{tabular}} & \multirow[b]{2}{*}{$t$} & \multirow[b]{2}{*}{ Sig. } \\
\hline & & $B$ & Std. Enror & & & \\
\hline 1 & (Constant) & 9.149 & .458 & & 19.990 & .000 \\
\hline & Opini Audit & .477 & .407 & .188 & 1.172 & .250 \\
\hline & Profitabilitas & .557 &, 167 & .542 & .3 .347 & .002 \\
\hline & Kompleksilas Operasi Perusahaan & $\cdot 246$ & .420 & .093 & .587 & .561 \\
\hline
\end{tabular}

Sumber: Ouput SPSS versi 23.

Berdasarkan tabel di atas, pengaruh variabel independen terhadap variabel dependen disajikan sebagai berikut:

Berdasarkan tabel 6 , pengaruh secara parsial opini audit terhadap audit report lag menunjukkan nilai thitung sebesar 1,172 $<$ ttabel $(0,05 / 2 ; 31)=2,039$ dan signifikansi sebesar $0,250<0,05$, maka H1 ditolak dan dapat dinyatakan bahwa opini audit secara parsial tidak berpengaruh terhadap audit report lag.
Berdasarkan tabel 6, pengaruh secara parsial profitabilitas terhadap audit report lag menunjukkan nilai thitung sebesar - 3,347 $<$ ttabel $(0,05 / 2 ; 31)=2,039$ dan signifikansi sebesar $0,02<0,05$, maka $\mathrm{H} 2$ diterima dan dapat dinyatakan bahwa profitabilitas secara parsial berpengaruh negatif signifikan terhadap audit report lag.

Berdasarkan tabel 6, pengaruh secara parsial kompleksitas operasi perusahaan terhadap audit report lag menunjukkannilai thitung sebesar - $0,587<$ ttabel $(0,05 / 2 ; 31)=2,039$ dan signifikansi sebesar $0,561>0,05$, maka H3 ditolak dan dapat dinyatakan bahwa kompleksitas operasi perusahaan secara parsial tidak berpengaruh terhadap audit report lag.

\section{Uji Statistik F}

Pengujian hipotesis uji $\mathrm{F}$ digunakan untuk melihat signifikan atau tidak pengaruh secara keseluruhan variabel independen terhadap variabel dependen. Dari hasil pengujian simultan diperoleh hasil sebagai berikut:

\section{Tabel 7 Uji Statistik F}

Sumber: Output SPSS versi 23.

\begin{tabular}{|c|c|c|c|c|c|c|}
\hline \multicolumn{7}{|c|}{ Allova } \\
\hline Mode & & Stm j: Squeres & $d f$ & Mean Squale & $\mathrm{F}$ & Sig. \\
\hline 1 & Regressicn & 14.783 & 3 & 4.923 & 4.256 & $.13^{3}$ \\
\hline & Residual & 35.395 & 31 & 1.153 & & \\
\hline & Tctal & 30.970 & 34 & & & \\
\hline
\end{tabular}

Berdasarkan tabel di atas untuk pengujian hipotesis secara simultan bahwa nilai Fhitung adalah $=4,256>\mathrm{F} 0,05(3,31)=2,91$ dengan tingkat signifikansi sebesar $0,013<0,05$, dengan demikian bahwa ketiga variabel yaitu opini audit, profitabilitas, kompleksitas operasi perusahaan, secara simultan berpengaruh signifikan terhadap audit report lag.

\section{Analisis Koefisien Determinasi (R Square)}

Analisis koefisien determinasi (R2) bertujuan untuk mengukur kemampuan variabel opini audit, profitabilitas, kompleksitas operasi perusahaan menjelaskan variasi audit report lag. 
Tabel 8 Analisis Koefisien Determinasi R2

\begin{tabular}{|l|r|l|r|c}
\hline Model & $R$ & R. Square & \multicolumn{1}{c|}{$\begin{array}{c}\text { Adjusted } R \\
\text { Square }\end{array}$} & Std. Error of the Estimate \\
\hline 1 & $.540^{\circ}$ & .252 & .223 & 1.07306 \\
\hline
\end{tabular}

Sumber: Output SPSS versi 23.

Berdasarkan tabel di atas, nilai koefisien determinasi (Adjusted R Square) sebesar 0,223 , hal ini dapat disimpulkan bahwa kemampuan variabel opini audit, profitabilitas, dan kompleksitas operasi perusahaan untuk menjelaskan variasi pada variabel dependen audit report lag sebesar $22,3 \%$ sedangkan sisanya $77,7 \%$ dipengaruhi atau dijelaskan oleh variabel lain yang tidak dimasukkan dalam penelitian ini seperti tingkat laba rugi, reputasi auditor, dan likuditas.

\section{Pengaruh Opini Audit Terhadap Audit Re- port Lag}

Dapat dinyatakan bahwa opini audit tidak berpengaruh terhadap audit report lag. Hal ini dapat dibuktikan dengan perhitungan variabel opini audit nilai thitung sebesar 1,172<ttabel $(0,05 / 2 ; 31)=2,039$ dan signifikansi sebesar $0,250>0,05$.

Artinya, jika pendapat auditor dalam menilai laporan keuangan perusahaandisajikan wajar atau tidak wajar tidak diikuti dengan peningkatan audit report lag. Hasil tersebut mendukung penelitian dari $\mathrm{Si}$ manjorang, R. M. (2018), hasil penelitiannya menunjukan bahwa secara parsial opini audit tidak berpengaruh terhadap audit report lag.

\section{Pengaruh Profitabilitas Terhadap Audit Report Lag}

Dapat dinyatakan bahwa profitabilitas berpengaruh negative dan signifikan terhadap audit report lag. Hal ini dapat dibuktikan dengan perhitungan variabel profitabilitas nilai thitung sebesar $-3,347<$ ttabel $(0,05 / 2 ; 31)=$ 2,039 dan signifikansi sebesar 0,02<0,05.

Artinya, jika profitabilitas mengalami peningkatan maka diikuti oleh peningkatan audit report lag. Hal ini disebabkan karena profitabilitas merupakan tingkat kemampuan perusahaan dalam menghasilkan laba bersih berdasarkan tingkat aset tertentu. Hasil terse- but mendukung penelitian yang dilakukan oleh Sastrawan, I. P., Latrini, M. Y. (2016), hasil penelitiannya menunjukan bahwasecara parsial profitabilitas berpengaruh negatif dan signifikan terhadap audit report lag.

\section{Pengaruh Kompleksitas Operasi Perusa- haan terhadap Audit Report Lag}

Dapat dinyatakan bahwa kompleksitas operasi perusahaan tidak berpengaruh terhadap audit report lag. Hal ini dapat dibuktikan dengan dengan perhitungan variabel kompleksitas operasi perusahaan nilai thitung sebesar$0,587<\operatorname{tabel}(0,05 / 2 ; 31)=2,039$ dan signifikansi sebesar 0,561>0,05.

Artinya, jika kompleksitas operasi perusahaan mengalami peningkatan maka tidak diikuti oleh peningkatan audit report lag. Hal ini disebabkan karena kompleksitas operasi perusahaan ditujukan dengan jumlah anak perusahaan. Hasil tersebut bertentangan dengan penelitian yang dilakukan oleh Fannisa (2018), hasil penelitiannya menunjukan bahwa secara parsial kompleksitas operasi perusahaan berpengaruh terhadap audit report lag.

\section{Pengaruh Opini Audit, Profitabilitas dan Kompleksitas Operasi Perusahaan Terha- dap Audit Report Lag}

Hasil pengujian hipotesis opini audit, profitabilitas, kompleksitas operasi perusahaan secara simultan berpengaruh signifikan terhadap audit report lag. Hasil ini dapat dilihat dari hasil uji $\mathrm{F}$ di nilai Fhitung adalah $=$ $4,256>\mathrm{F} 0,05(3,31)=2,91$ dengan tingkat signifikansi sebesar $0,013<0,05$.

Besarnya nilai Adjusted R Square sebesar sebesar 0,223, hal ini dapat disimpulkanbahwa kemampuan variabel opini audit, profitabilitas, dan kompleksitas operasi perusahaan untuk menjelaskan variasi pada variabel dependen audit repor tlag sebesar 22,3\% sedangkan sisanya $77,7 \%$ dipengaruhi atau dijelaskanoleh variabel lain yang tidak dimasukkan dalam penelitian ini seperti tingkat laba rugi, reputasi auditor, dan likuditas.

\section{KESIMPULAN}

Berdasarkan penelitian yang dilakukan maka diperoleh kesimpulan sebagai berikut:

Pengaruh secara parsial opini audit terha- 
dap audit Report Lagmenunjukkan nilai thitung sebesar $1,172<$ ttabel $(0,05 / 2 ; 31)=$ 2,039 dan signifikan sebesar 0,250>0,05, maka $\mathrm{H} 1$ ditolak dan dapat dinyatakan bahwa opini audit secara parsial tidak berpengaruh terhadap audit report lag.

Pengaruh secara parsial profitabilitas terhadap audit report lag menunjukkan nilai thitung sebesar $-3,347<$ ttabel $(0,05 / 2 ; 31)=$ 2,039 dan signifikan sebesar $0,02<0,05$, maka H2 diterima dan dapat dinyatakan bahwa profitabilitas secara parsial berpengaruh negatif signifikan terhadap audit report lag.

Pengaruh secara parsial kompleksitas operasi perusahaan terhadap audit report lag menunjukkan nilai thitung sebesar $-0,587$ $<$ ttabel $(0,05 / 2 ; 31)=2,039$ dan signifikan sebesar 0,561 >0,05, maka H3 ditolak dan dapat dinyatakan bahwa kompleksitas operasi perusahaan tidak berpengaruh terhadap audit report lag.

Berdasarkan pengujian hipotesis secara simultan (uji F) bahwa nilai Fhitung adalah $4,256>\mathrm{F} 0,05(3,31)=2,91$ dengan tingkat signifikansi sebesar $0,013<0,05$, dengan demikian bahwa ketiga variabel yaitu opini audit, profitabilitas, kompleksitas operasi perusahaan secara simultan berpengaruhsignifikan terhadap audit report lag.

\section{DAFTAR PUSTAKA}

Abadi, Yoga Setya. (2017). Pengaruh Profitabilitas, Ukuran Perusahaan, Kompleksitas Operasi Perusahaan dan Reputasi KAP terhadap Audit Report Lag(Studi Empiris Perusahaan Manufaktur Terdaftar di Bursa Efek Indonesia Periode 2013-2015). Skripsi Jurusan Akuntansi Fakultas Ekonomi dan Bisnis Universitas Muhammadiyah Surakarta.

Ahmed, Mohammed Ishaq \& Che-Ahmad Ayoib. (2016). International JournalofEconomicsand Financial Issues, 6(S7) 159-164.

Amariyah, Siti, dkk. (2017). Pengaruh Profitabilitas, Solvabilitas dan Umur Perusahaan terhadap Audit Report Lagpada Perusahaan Manufaktur yang Terdaftar di Bursa Efek Indonesia Periode 2013-
2015. Jurnal Ekonomi Akuntansi, Vol.

3. Issue. 3.

Arumsari, Vivien Fitriana \& Handayani, Nur. 2017. Pengaruh Kepemilikan, Profitabilitas, Leverage dan Opini Audit Terhadap Audit Delay. Jurnal Ilmu dan Riset Akuntansi, Vol. 6 No. 4, Hal. 1364-1379.

Atmojo. Danang Tri \& Darsono.2017. Analisis Faktor-Faktor yang Berpengaruh Terhadap Audit Report Lag. Diponegoro Journal of Accounting, Vol. 6 No. 4 Hal. 1-15.

Bambang Hartadi. (2013). Auditing. Suatu Pedoman Pemeriksaan Akuntansi Tahap Pendahuluan. Yogyakarta: BPFE.

Bae, Chang-Hyun \& Woo, Yong-Sang. (2016). The effectof CEO turn over on audit Report Lagand management discretionary report lag: evidence from Korea. Journal Investment Management and Financial Innovations, 13(1), 61-66.

Damayanti, Yunisdha Nuvika. (2017). Pengaruh Opini Audit, Ukuran KAP, Profitabilitas dan Kompleksitas Operasi Perusahan terhadap Audit Report Lagpada Perusahaan Pertambangan yang Terdaftar di BEI Periode 2013- 2015. Skripsi Jurusan Ekonomi dan Bisnis Fakultas Ekonomi dan Bisnis Universitas $\mathrm{Mu}-$ hammadiyah Surakarta.

Dasila, Rifqa Ayu \&Hajering. (2019). Pengaruh Pengalaman, Inependensi dan Skeptisme Profesional Auditor terhadap Pendeteksian Fraud. Jurnal Ilmu Ekonomi, Volume 2 Nomor 1. Januari.

Dura, Justita. (2017). Pengaruh Profitabilitas, Likuiditas, Solvabilitas dan Ukuran Perusahaan terhadap Audit Report Lagpada Perusahan Manufaktur yang Terdaftar di Bursa Efek Indonesia. JIBEKA, Volume 11 Nomor 1: 64 - 70. Februari.

Eksandy, Arry. 2017. Pengaruh Ukuran Perusahaan, Solvabilitas, Profitabilitas dan Komite Audit Terhadap Audit Delay. Jurnal Akuntansi dan Keuangan, Vol. 1 No. 2.

Fannisa, Sheila. (2018). Pengaruh Ukuran KAP, Ukuran Perusahaan, Profitabilitas 
dan Kompleksitas Operasi Perusahaan Terhadap Audit Report Lagpada Perusahaan Pertambangan yang Terdaftar di Bursa Efek Indonesia Periode 20142016. Skripsi Jurusan Akuntansi Fakultas Ekonomi dan Bisnis Universitas Sumatera Utara Medan.

Ghozali, Imam. Aplikasi Analisis Multivariate dengan Program SPSS. Cetakan ke empat. Semarang: Undip, 2013.

. \&Latan, H. (2015). Konsep, Teknik dan Aplikasi Menggunakan Smart PLS 3.0. Edisi 2. Universitas Diponegoro: PartialLeastSquares.

Gunarsa, I Gede Aditya Cahya \&Igam Asri Dwija Putri. (2017). Pengaruh Komite Audit, Independensi Komite, dan Profitabilitas terhadap Audit Report Lagdi Perusahaan Manufaktur. E-Jurnal Akuntansi Universitas Udayana, 30(2); 16721703.

Hapsari, Adlina Nindra, dkk. (2016). The Influence of Profitability, Solvency, and Auditor's Opinion to Audit Report Lagat Coal Mining Companies. Binus Business Review, 7(2), 197 201.Agustus.

Hariani, dkk. (2014). Faktor-faktor pemengaruh audit Report Lag(studi empiris pada perusahaan-perusahan di Bursa Efek Indonesia). Diponegoro Journal of Accounting, 3(2); 1-9.

Hastuti, Linda Puji \& Sugeng, Santoso. 2017. Pengaruh Solvabilitas, Ukuran KAP, Umur Perusahaan dan Komite Audit Terhadap Audit Delay pada Perusahaan Tekstil dan Garment. Jurnal Penelitian dan Kajian Ilmiah Fakultas Ekonomi Universitas Surakarta, Vol. 15 No. 1. Hal. 27-33.

Ikatan Akuntansi Indonesia. (2012). Standar Profesional Akuntan Publik (SPAP). Jakarta: Salemba Empat.

Kuslihaniati, Desi Fia. (2016). Pengaruh Praktik Corporate Governance dan Karakteristik Perusahaan terhadap Audit Report Lag. Jurnal ilmu dan Riset Akuntansi, 5(2); 1-22.

Lapinayanti, Ni Made Mega \& Budiartha, I Ketut. 2018. Pengaruh Profitabilitas dan
Leverage pada Audit Delay dengan Ukuran Perusahaan Sebagai Pemoderasi. E-Jurnal Akuntansi Universitas Udayana, Vol. 23,2. Hal 1066-1092.

Lestari, Alit Sri. Pengaruh Solvabilitas, Ukuran Perusahaan, Opini Audit dan Ukuran Kap terhadap Audit Report Lag (Studi Empiris Perusahaan terhadap Audit Report Lagdengan Komite Audit Sebagai Variabel Moderating (Studi pada Perusahaan Manufaktur yang Terdaftar di BEI Tahun 2015-2017). Skripsi Jurusan Akuntansi Fakultas Ekonomi dan Bisnis Universitas Islam Negeri Alauddin Makassar.

S, Defri Prananda, dkk. (2016). Pengaruh Leverage, Kompleksitas Operasi Perusahaan, Reputasi Auditor dan Laba/Rugi Operasi Perusahaan terhadap Audit Delay (Studi pada Perusahaan Perdagangan, Jasa dan Investasi yang Terdaftar di Busra efek Indonesia Tahun 20132015). Majalah Ilmiah UNIKOM, Vol. 15 No. 2.

Sastrawan, I Putu \&Latrini, Made Yenni. (2016). Pengaruh Profitabilitas, Solvabilitas dan Ukuran Perusahaan terhadap Audit Report Lagpada Perusahaan Manufaktur. E-Jurnal Akuntansi Universitas Udayana, Vol.17.1: 311-337. Oktober.

Simaronjang, Reka Melina. (2018). Pengaruh Profitabilitas, Opini Audit, Pergantian Auditor, dan Ukuran Perusahaan terhadap Audit Report Lagpada Perusahaan Manufaktur yang Terdaftar di Bursa Efek Inonesia Periode 2014-2016. Skripsi Jurusan Akuntansi Fakultas Ekonomi dan Bisnis Universitas Sumatera Utara Medan.

Sugiyono. (2017). Metode Penelitian Kuantitatif, Kualitatif dan R\&D. Bandung: Penerbit Alfabeta. Pada PerusahaanManufaktur yang. (2012). Metode Penelitian Kuantitatif, Terdaftar Di BEI Periode 2011-2013). Jom FEKON, 2(2), 2015; 1-14.

Lestari, Ni Luh Ketut Ayu Sathya \& Latrini, Made Yenni. (2018). Pengaruh Fee Audit, Ukuran Perusahaan Klien, Ukuran 
33 AKUNSIKA, Vol 2, No 1, Januari 2021, hal 01 -

Kap, dan Opini Auditor Pada Audit Delay. E-Jurnal Akuntansi Universitas Udayana, Vol.24.1: 422 - 450. Juli.

Rosdiana. (2018). Pengaruh Company Size, Profitabilitas dan Kompleksitas Operasi Kualitatif dan R\&D. Bandung: Penerbit Alfabeta.

Suherdi, Arief. (2018). Pengaruh Kompleksitas Operasi Perusahaan, Profitabilitas dan Ukuran Perusahaan terhadap Ketepatan Waktu Pelaporan Keuangan (Timelienessof Financial Reporting). Skripsi Fakultas Ekonomi Universitas Islam Indonesia Yogyakarta.

Wiryakriyana, Anak Gedung Gede \& Widhiyani, Ni Luh Sari. 2017. Pengaruh Ukuran Perusahaan, Leverage, Auditor Switching dan Sistem Pengendalian Internal pada Audit Delay. E-Jurnal Akuntansi Universitas Udayana, Vol. 19,1. Hal. 771-798.

Wiyantoro, L. S. \& Usman, F. (2018). Audit Tenure and Quality to Audit Report Lagin Banking. European Research StudiesJournal, Volume XXI, Issue 3. 